\title{
Efficient removal of spores from skim milk using cold microfiltration: Spore size and surface property considerations
}

\author{
Emily R. Griep, Yifan Cheng, and Carmen I. Moraru ${ }^{1}$ \\ Department of Food Science, Cornell University, Stocking Hall, Ithaca, NY 14853
}

\begin{abstract}
Bacterial spores present in milk can cause quality and shelf-life issues for dairy products. The objectives of this study were to evaluate the effectiveness of microfiltration (MF) in removing Bacillus licheniformis and Geobacillus sp. spores from skim milk using membranes with pore sizes of 1.4 and $1.2 \mu \mathrm{m}$, and to investigate the role of spore surface properties in MF removal. Cell sizes were determined by scanning electron microscopy, surface charge by zeta potential analysis, and surface hydrophobicity by contact angle measurements. Commercially pasteurized skim milk was inoculated with a spore suspension at about $10^{6} \mathrm{cfu} / \mathrm{mL}$, and then processed by MF using ceramic membranes at $6^{\circ} \mathrm{C}$, a crossflow velocity of $4.1 \mathrm{~m} / \mathrm{s}$, and transmembrane pressure of 69 to $74 \mathrm{kPa}$. Total aerobic plate and spore counts in the milk were determined before and after MF. All processing runs and surface and product analyses were conducted in triplicate, and data were analyzed statistically. For the same strain, spores were shorter and wider than vegetative cells, averaging 1.37 to $1.59 \mu \mathrm{m}$ in length and 0.64 to $0.81 \mu \mathrm{m}$ in width. Reduction of $B$. licheniformis spores significantly increased with a reduction in MF pore size, from $2.17 \log$ for $1.4-\mu \mathrm{m}$ pore size, to $4.57 \log$ for $1.2-\mu \mathrm{m}$ pore size. Both pore sizes resulted in almost complete removal of Geobacillus sp. spores. All spores and the ceramic membrane had a negative surface charge at milk $\mathrm{pH}$, indicating an electrostatic repulsion between them. Bacillus licheniformis spores were hydrophilic, whereas Geobacillus sp. spores were hydrophobic. Consequently, Geobacillus sp. spores had a tendency to cluster in skim milk, preventing their passage even through the 1.4- $\mu \mathrm{m}$ MF membrane, whereas some B. licheniformis spores could still pass through a $1.2-\mu \mathrm{m}$ membrane. This study demonstrates that efficient removal of spores from skim milk by cold MF may require a smaller membrane pore size than required for removal of vegetative cells of the same spe-
\end{abstract}

Received April 6, 2018.

Accepted June 28, 2018.

${ }^{1}$ Corresponding author: cim24@cornell.edu cies, and that cell surface properties may interfere with the outcome of filtration as would be anticipated based on size alone.

Key words: microfiltration, spore removal, skim milk

\section{INTRODUCTION}

The presence of spore-forming bacteria in milk is a critically important issue in the dairy industry. Bacterial endospores can survive in harsh environmental conditions such as high heat, low $\mathrm{pH}$, desiccation, or cleaning and sanitizing chemicals (Scheldeman et al., 2006; Burgess et al., 2010; Ranieri and Boor, 2010). Compared with vegetative cells, spores have also been found to attach more readily to stainless steel, leading to the formation of biofilms that can promote bacterial contamination within dairy processing plants (Rönner et al., 1990; Parkar et al., 2001; Palmer et al., 2010). Spores present in final products can germinate and produce enzymes that decrease dairy product quality and shelf life, causing significant economic losses (Crielly et al., 1994; Postollec et al., 2012; Lücking et al., 2013). Additionally, some sporeformers such as Bacillus cereus and Bacillus subtilis can produce toxins that are responsible for food poisoning (De Jonghe et al., 2010). Thermophilic Geobacillus spp. and Anoxybacillus spp. are other sporeformers of importance to the dairy industry, as they are commonly isolated from dairy powders and evaporated milk (Rückert et al., 2004; Scheldeman et al., 2006; Watterson et al., 2014). Removal of all these spores from milk can result in significant improvements in quality and shelf life of dairy products.

Microfiltration (MF) is an effective nonthermal method for removing bacteria and somatic cells from skim milk, while maintaining milk quality virtually unchanged. Microfiltration is used in the industry to produce extended-shelf-life milk, and as a potential pretreatment of skim milk intended for the manufacture of dairy powders or cheese. Previous studies reported average reductions of vegetative bacteria from 3 to 6 $\log \mathrm{cfu} / \mathrm{mL}$ when using MF membranes with a pore size of $1.4 \mu \mathrm{m}$ for microbial removal from skim milk (Elwell and Barbano, 2006; Hoffmann et al., 2006; Schmidt 
et al., 2012). However, Schmidt et al. (2012) reported that two-thirds of commercial extended-shelf-life milk produced in Germany, Austria, and Switzerland using MF followed by pasteurization underwent spoilage by B. cereus and Paenibacillus spp., suggesting that although MF membranes of $1.4-\mu \mathrm{m}$ pore size can remove vegetative cells, they may not sufficiently eliminate spores, which may be smaller than vegetative cells of the same species. Spores of Bacillus spp. were reported to range from 1.07 to $1.74 \mu \mathrm{m}$ in length and 0.48 to $0.98 \mu \mathrm{m}$ in diameter (Leuschner et al., 1999; Carrera et al., 2007), and thus some may pass through a 1.4$\mu \mathrm{m}$ membrane. Reducing the membrane pore size may improve spore reduction. For example, Tomasula et al. (2011) reported average 4.50- and 5.91-log reductions of Bacillus anthracis (Sterne) from skim milk using 1.4and $0.8-\mu \mathrm{m}$ ceramic membranes, respectively, but the $0.8-\mu \mathrm{m}$ membrane led to significant protein reduction in the permeate, suggesting that this pore size may be too small for maintaining the skim milk composition.

Factors other than size may also play a role in bacterial spore removal by MF. For example, surface structural elements, such as proteins or exosporium, or surface properties, such as hydrophobicity and electrostatic potential, can influence the interactions between cells, as well as between cells and the membrane surface (Seale et al., 2008; Palmer et al., 2010; Feng et al., 2015). Temperature is a critical parameter in membrane filtration, and its effect on bacteria removal needs to be considered. In the dairy industry, bacterial removal by MF is typically conducted under warm conditions, at temperatures between 50 and $55^{\circ} \mathrm{C}$. Although conducting MF warm can maximize permeate flux, these condition also allow for optimum growth of thermophilic (Geobacillus spp. and Anoxybacillus spp.) or facultative thermophilic (certain strains of Bacillus spp.) sporeformers (Burgess et al., 2010). Warm MF may thus promote the growth of sporeformers within the membrane and recirculation loop of the MF system, which can result in microbial fouling of the MF membranes (Kochkodan et al., 2006; Tang et al., 2009; Anand et al., 2014). This could then lead to formation of highly resistant biofilms, which can serve as a reservoir of bacteria and propagate recontamination in the system and in the final product (Flint et al., 2001; Parkar et al., 2001). Low-temperature MF has therefore been proposed as a solution to reduce the risk of bacterial growth during membrane processing (Fritsch and Moraru, 2008; Walkling-Ribeiro et al., 2011).

Studies focusing on the specific removal of spores relevant to dairy product quality using MF are very limited. Elwell and Barbano (2006) and Fritsch and Moraru (2008) detected no spores in skim milk subjected to MF with a 1.4- $\mu \mathrm{m}$ membrane, under either warm (the former) or cold (the latter) conditions. However, in these studies, the initial raw milk had a very low spore count, and thus the results are inconclusive regarding the full potential of MF for spore retention. To address this gap, the main objective of the current study was to evaluate the effectiveness of $1.2-$ and $1.4-\mu \mathrm{m}$ pore size membranes on the removal of vegetative cells and bacterial spores from skim milk by cold MF. Additionally, the cell size and surface properties of the challenge microorganisms were determined and their impact on physical removal by MF was evaluated. As challenge organisms, vegetative cells and spores of $B$. licheniformis and Geobacillus sp. were used. The 2 microorganisms are recognized culprits for dairy product spoilage (Burgess et al., 2010; Lücking et al., 2013; Watterson et al., 2014). The findings of this study can be used to develop more efficient MF processes for the removal of spores from milk, leading to the production of dairy products with improved quality and shelf life.

\section{MATERIALS AND METHODS}

\section{Production of Bacterial Spore Suspensions}

The procedure for producing the spore suspensions was adapted from Gaillard et al. (1998), with minor modifications, and is described below.

Inoculation and Plating. Isolated cultures of $B$. licheniformis (FSL strain F4-0073) and Geobacillus sp. (FSL strain W8-0032) were obtained from the Cornell Milk Quality Improvement Program (Department of Food Science, Ithaca, NY). Five milliliters of brain heart infusion broth (BBL, Becton Dickinson and Co., Franklin Lakes, NJ) was inoculated with cultures of each study species and incubated overnight $(B$. licheniformis at $32^{\circ} \mathrm{C}$; Geobacillus sp. at $55^{\circ} \mathrm{C}$ ). A volume of $250 \mu \mathrm{L}$ of culture was plated onto sporulation agar. Bacillus licheniformis was sporulated on $\mathrm{AK} \# 2$ agar (BBL, Becton Dickinson and Co.) at $32^{\circ} \mathrm{C}$ for an average of $10 \mathrm{~d}$, and Geobacillus sp. was sporulated on tryptone glucose extract agar (Difco, Becton Dickinson and Co.) with $10 \mathrm{mg} / \mathrm{L}$ manganese sulfate at $55^{\circ} \mathrm{C}$ for an average of $21 \mathrm{~d}$. Sporulation was monitored during incubation by staining with $0.5 \%$ malachite green solution. Spores were harvested when staining showed sporulation of $\geq 95 \%$.

Harvesting. To harvest spores, $15 \mathrm{~mL}$ of sterile phosphate buffer (Weber Scientific, Hamilton, NJ) was added to the agar surface. Cells were scraped off using a sterile loop, and the resulting suspension was collected in a sterile centrifuge tube. Suspensions were centrifuged at $4^{\circ} \mathrm{C}$ using a Beckman Avanti J-25 centrifuge (Beckman Coulter, Fullerton, CA). Centrifugation was conducted at $11,086 \times g$ for $10 \mathrm{~min}$ for $B$. 
licheniformis, and 17,510 $\times g$ for 15 min for Geobacillus sp. The supernatant was drained and resuspended in a $50 \%$ ethanol solution for up to $3 \mathrm{~d}$ at 4 to $6^{\circ} \mathrm{C}$. Following storage in ethanol, suspensions were recentrifuged and the supernatant was drained. Spores were washed 3 times and resuspended in sterile phosphate buffer. Final suspensions were stained with $0.5 \%$ malachite green solution and checked microscopically to ensure that no germination occurred during harvesting. To determine suspension concentration $(\mathrm{cfu} / \mathrm{mL})$, an aerobic plate count was performed with serial dilutions in $0.1 \%$ peptone (Difco, Becton Dickinson and Co.) spread plating in duplicate on brain heart infusion agar at $32^{\circ} \mathrm{C}(B$. licheniformis) or $55^{\circ} \mathrm{C}$ (Geobacillus sp.) for $48 \mathrm{~h}$ (Frank and Yousef, 2004). Final suspensions were stored at 4 to $6^{\circ} \mathrm{C}$ until use.

\section{Physical Characterization of Bacterial Spores}

Imaging by Scanning Electron Microscopy. Samples were prepared for scanning electron microscopy imaging according to Feng et al. (2014). A piece of glass coverslip was broken into pieces of $\sim 0.5-\mathrm{cm}^{2}$ and thoroughly rinsed in acetone, ethanol, and MilliQ water (Millipore Sigma, Burlington, MA). Rinsing was followed by $1 \mathrm{~h}$ of sonication in fresh MilliQ water. To fix the samples onto the substrate, $10 \mu \mathrm{L}$ of spore or vegetative cell suspension was pipetted onto a piece of clean coverslip, air-dried under a biosafety hood for 1 $\mathrm{h}$, and then fixed with $2.5 \%$ (wt/vol) glutaraldehyde in $0.05 \mathrm{M}$ sodium cacodylate buffer at $4^{\circ} \mathrm{C}$ for $2 \mathrm{~h}$. After this, samples were rinsed 3 times in cacodylate buffer for $5 \mathrm{~min}$ per rinse, and then treated with $1 \%$ (wt/vol) osmium tetroxide in cacodylate buffer for $1 \mathrm{~h}$. Subsequently, samples were rinsed in cacodylate buffer 3 times and sequentially dehydrated in 10-min steps using $25 \%$ (vol $/ \mathrm{vol}$ ), $50 \%, 70 \%, 95 \%$, and $100 \%$ ethanol solutions, respectively. After dehydration, samples were dried to critical point with carbon dioxide. The dried surfaces were mounted onto scanning electron microscopy stubs and coated with evaporated carbon. The scanning electron microscopy imaging of spores and vegetative cells was conducted with a Zeiss LEO 1550 field emission scanning electron microscope (Carl Zeiss Microscopy LLC, Hamburg, Germany), at a voltage of $3 \mathrm{kV}$. Micrographs were acquired using SmartSEM software (Carl Zeiss Microscopy LLC).

The dimensions of vegetative cells and spores were determined on scanning electron micrographs using ImageJ analytical software (W. S. Rasband; National Institutes of Health, Bethesda, MD). Average dimensions were calculated using sets of 9 to 19 cells. A Gaussian distribution of cell size was developed based on the average length and range for each strain, and used to estimate the probability of cells to be larger or smaller than the membrane pore size (1.2 and $1.4 \mu \mathrm{m}$, respectively). The detailed methodology for these calculations can be found in Supplemental File S1 (https: //doi.org/10.3168/jds.2018-14888).

Contact Angle Measurement of Bacterial Spores and the Ceramic Membrane. Contact angles of water, glycerol, and diiodomethane on lawns of bacterial spores and vegetative cells were determined by the sessile drop method with a Rame-Hart 500 goniometer (Rame-Hart Inc., Succasunna, NJ), as described previously by Feng et al. (2014). Contact angles of the active layer of a cleaned, unused ceramic MF membrane were also measured.

To prepare the bacterial lawns, $30 \mathrm{~mL}$ of spore or vegetative cell suspension was centrifuged for $10 \mathrm{~min}$ at $1,789 \times g$ and $4^{\circ} \mathrm{C}$ using a Hettich Universal $32 \mathrm{R}$ centrifuge (Hettich Lab, Tuttlingen, Germany). The resulting pellet was resuspended with Butterfield phosphate buffer (BPB) formulated to simulate the $\mathrm{pH}$ and ionic strength of milk $(\mathrm{pH}=6.8$, ionic strength $=$ $0.8 \mathrm{M}$, at $6^{\circ} \mathrm{C}$ ). The suspension was centrifuged again under the same conditions to ensure total replacement of the initial suspension medium by a milk-mimicking BPB. After the supernatant was decanted, the pellet was resuspended with $15 \mathrm{~mL}$ of fresh $\mathrm{BPB}$ to double the concentration. Two $15-\mathrm{mL}$ tubes of the resultant suspension were filtered through a $0.22-\mu \mathrm{m}$ polyethersulfone membrane (47 mm diameter, Millipore Express Plus; Merck Millipore Ltd., Billerica, MA) using a magnetic filtration funnel, leading to the formation of a bacterial lawn. The lawn was dried and mounted onto a glass slide before contact angle measurement.

Measurement of Zeta Potential. Following the procedure described by Feng et al. (2014), the zeta potential of spores and vegetative cells was measured in $\mathrm{BPB}\left(\mathrm{pH} 6.8\right.$, ionic strength $=0.8 \mathrm{M}$, at $6^{\circ} \mathrm{C}$ ) using a Malvern Zetasizer nano-ZS with disposable folded capillary cells (Malvern Instruments, Malvern, UK). To measure the surface zeta potential of the ceramic filtration membrane, an unused membrane was cut to the size of the plastic stage on which it was to be mounted. Membrane sections were cleaned and mounted via double-sided tape to the stage. The membrane's active surface was oriented toward the electrodes, and the stage was placed between the electrodes of a surface zeta potential cell (Malvern Instruments). The probe was submerged in $1.0 \mathrm{~mL}$ of tracer particle suspension (Malvern Instruments) contained in a plastic cuvette. Measurements of electrophoretic mobility of tracer particles at $125,250,375,500$, and $625 \mu \mathrm{m}$ from the planar surface of the MF membrane surface were taken at $6^{\circ} \mathrm{C}$. The magnitude of particle electrophoresis and electroosmosis generated by the surface charge were used to 
derive the zeta potential at the wall surface following the methods of Corbett et al. (2012). Electrophoretic measurements were averages of at least 20 internal repetitions; triplicate measurements were performed and averaged to calculate the apparent zeta potential values at each distance from the surface. Measurements of electrophoretic velocity of tracer particles were repeated 3 times, with averaging of 30 internal measurements for each repeat, at 1,000 $\mu \mathrm{m}$ from the surface.

Gibbs Free Energy Calculations. The change in Gibbs free energy was used as a thermodynamic indicator of cell-cell and cell-surface interactions, which considers acid-base and van der Waals forces. The method for calculating the Gibbs free surface energy of aggregation $\left(\Delta G_{\mathrm{bwb}}\right)$ and surface energy of attachment $\left(\Delta G_{\mathrm{bws}}\right)$ from the contact angle measurements, as well as the individual surface energy components can be found in Supplemental File S1 (Table S1; https: //doi.org/10.3168/jds.2018-14888). It should be noted that the physico-chemical constants used to calculate the Gibbs free energy were measured at $20^{\circ} \mathrm{C}$, and thus the calculated values would hold for this temperature. To accurately account for the effect of temperature on hydrophobic interactions, the Gibbs free energy of aggregation was also calculated at $6^{\circ} \mathrm{C}$ by extrapolating the values of surface tension components $\left(\gamma_{\mathrm{LW}}\right.$ and $\left.\gamma_{\mathrm{AB}}\right)$ at $6^{\circ} \mathrm{C}$ from the study of Zdziennicka et al. (2017).

\section{MF Experiments}

A pilot-scale MF unit consisting of a $50-\mathrm{L}$ feed tank with a variable speed centrifugal pump, heat exchanger, and membrane housing, equipped with Isoflux tubular ceramic membranes of Tami design (GEA Filtration, Hudson, WI) was used. Membranes were 1,200 mm long and had an outer diameter of $25 \mathrm{~mm}, 23$ internal channels of 3.5-mm hydraulic diameter each, and a total membrane area of $0.35 \mathrm{~m}^{2}$. Two new membranes with pore sizes of 1.4 and $1.2 \mu \mathrm{m}$ were used throughout the study.

An inline temperature probe was used to monitor the temperature, and pressure gauges were used to measure feed inlet $\left(\mathrm{P}_{\mathrm{i}}\right)$ and feed outlet $\left(\mathrm{P}_{\mathrm{o}}\right)$ pressure. The transmembrane pressure (TMP) was calculated using the equation:

$$
\mathrm{TMP}=\frac{\left(P_{i}+P_{o}\right)}{2}-P_{p},
$$

where $P_{i}$ is feed inlet pressure, $P_{o}$ is feed outlet pressure, and $P_{p}$ is permeate pressure.

Before each experimental run, the MF unit, previously chemically cleaned, was sterilized with hot water $\left(80^{\circ} \mathrm{C}\right)$ for $30 \mathrm{~min}$. Pasteurized skim milk, obtained from the Cornell Dairy Plant (Ithaca, NY), was stored at $6^{\circ} \mathrm{C}$ until the MF run. The B. licheniformis experiments were conducted on 3 separate days each for the 1.2- and 1.4- $\mu \mathrm{m}$ pore sizes during June and July 2015. Geobacillus sp. experiments were similarly conducted on 3 days during September and October 2015.

A volume of 200 to $400 \mathrm{~mL}$ of spore suspension of known concentration was centrifuged, the phosphate buffer decanted, and a spore pellet recovered. The spore pellet was then resuspended in aseptically collected skim milk, and this suspension was then used for direct inoculation of the skim milk in the feed tank of the MF unit.

Microfiltration of the inoculated skim milk was conducted at $6^{\circ} \mathrm{C}$ with a cross-flow velocity of $4.14 \pm 0.01$ $\mathrm{m} / \mathrm{s}$. The TMP averaged $73.11 \pm 5.93$ and $69.87 \pm 1.62$ $\mathrm{kPa}$ for the 1.4- and $1.2-\mu \mathrm{m}$ processing runs, respectively. These MF parameters were selected to minimize fouling, based on the study by Fritsch and Moraru (2008), because excessive fouling could have caused inflated spore removal counts unrepresentative of true membrane selectivity. For the same reason, MF processing was only conducted for a short duration (18 to 19 min), sufficient to collect enough permeate for analysis without significant fouling of the membrane. Permeate samples were collected aseptically using an inline sampling port and sterile sampling assembly (Quality Management Inc., Oakdale, MN). The collected sample bags were immediately placed on ice or in refrigerated storage until analysis, which was conducted within 2 $\mathrm{h}$ of collection. The MF experiments were conducted in triplicate for each spore species and each membrane pore size.

Following each MF run, membranes were chemically cleaned starting with a 10-min reverse osmosis (RO) water rinse. This was followed by a 30-min alkaline clean using $17.5 \mathrm{~mL} / \mathrm{L}$ of Ultrasil-25 (Ecolab, St. Paul, $\mathrm{MN}$ ) at $80^{\circ} \mathrm{C}$, followed by a second 10 -min $\mathrm{RO}$ water rinse, a 20-min acid cleaning using $5 \mathrm{~mL} / \mathrm{L}$ of $\mathrm{HNO}_{3}$ at $50^{\circ} \mathrm{C}$, and a final $\mathrm{RO}$ water rinse. Water flux measurements were conducted before and after MF runs to monitor cleaning efficacy and any changes in membrane performance over time.

\section{Microbiological Analyses}

Preinoculated pasteurized milk and MF permeate samples were tested for mesophilic spore counts for $B$. licheniformis challenge studies and thermophilic spore counts for the Geobacillus sp. challenge studies, using the methodology of Frank and Yousef (2004). Briefly, to determine the spore counts, a spore pasteurization step was completed as follows: samples were heated and 
held at $80^{\circ} \mathrm{C}$ for $12 \mathrm{~min}$, and then cooled to $6^{\circ} \mathrm{C}$ before sample dilution and plating. This step is necessary to destroy vegetative cells in the sample and germinates spores, ensuring a final count of only bacterial spores. Serial dilutions were spread plated in duplicate on brain heart infusion agar at for $48 \mathrm{~h}$ (mesophilic at $32^{\circ} \mathrm{C}$; thermophilic at $55^{\circ} \mathrm{C}$ ). All plates were counted and results expressed in log colony-forming units per milliliter.

\section{Composition Analyses}

The chemical composition of the milk samples was determined using a Milkoscan Minor (Foss, Hillerød, Denmark) in duplicate.

\section{Statistical Analyses}

Data were analyzed using RStudio statistical software (version 3.2.2, RStudio Inc., Boston, MA). Statistical differences among observed means were determined using an unpaired $t$-test with a significance level $\alpha=0.05$.

\section{RESULTS AND DISCUSSION}

\section{MF with Different Pore Sizes: Effect on Spore Removal, Milk Quality, and Flux}

Microfiltration using the $1.2-\mu \mathrm{m}$ membrane resulted in a significantly $(P<0.005)$ greater reduction of $B$. licheniformis spores (4.57 log \pm 0.09$)$ than the 1.4- $\mu \mathrm{m}$ membrane (2.17 log \pm 0.64 ; Table 1). For Geobacillus sp., spore counts in the MF milk were below the detection limit, indicating near-complete reduction $(>6 \log )$ for MF with both pore sizes. Although the nominal pore size of the $1.2-\mu \mathrm{m}$ membrane was considerably larger than the size of all milk components (excluding the milk fat globules), this membrane also resulted in a greater retention of milk components than the 1.4- $\mu \mathrm{m}$ membrane, as shown in Table 2. Although the largest percentage reduction of all components occurred for milk fat, the initial fat content of the milk was very low $(\sim 0.22 \%)$, because the MF was conducted using skim milk. Lactose content was only minimally affected by MF, because lactose is a small, soluble molecule and thus not retained by MF membranes. Most substantial was the reduction of milk proteins in the MF permeate, with reductions of $\sim 4 \%$ for the $1.4-\mu \mathrm{m}$ membrane and $\sim 10 \%$ for the $1.2-\mu \mathrm{m}$ membrane. This is most likely due to retention of casein micelles, which was enhanced by the smaller pore size. Brans et al. (2004) suggested that the bridging of casein micelles can lead to partial pore blocking of MF membranes. Tan et al. (2014) also found that casein micelles were a major cause of fouling in cold MF using a 1.4- $\mu \mathrm{m}$ membrane, because of micelle interaction and binding to the membrane surface. Minimizing protein retention is very important for the implementation of MF in the dairy industry, because protein is an important component of skim milk, from both a nutritional and an economical point of view. Optimization of processing parameters for 1.2- $\mu \mathrm{m}$ MF can identify the processing parameters that appropriately balance maximum bacterial removal, minimum protein retention, and maximum flux. Additionally, the MF retentate, which has both a high protein content and a high bacterial count, can be separately processed using high heat and later recombined with the permeate, as described by Holm et al. (1986).

The greater retention of these milk components was reflected in the lower flux values and slightly higher flux drop over time obtained for the $1.2-\mu \mathrm{m}$ membrane compared with the 1.4- $\mu \mathrm{m}$ membrane (Figure 1). In Figure 1 , data were grouped for the 2 types of spores, because some irreversible membrane fouling may have occurred with time and because slight seasonal changes in milk composition could have affected the filterability of the milk. Although the flux values for the 2 membrane pore sizes did not differ statistically within a spore species due to the large variability of the data, similar trends were observed for both spore challenges. These data align well with the changes in composition reported for the Geobacillus sp. challenge reported above.

Nonetheless, the most remarkable result in this study was the much higher reduction of $B$. licheniformis

Table 1. Average reduction $( \pm \mathrm{SD})$ of bacterial spores by microfiltration $(\mathrm{MF})$ processing $(\mathrm{n}=3)$

\begin{tabular}{lccc}
\hline Challenge study & $\begin{array}{c}\text { Initial load } \\
(\log \mathrm{cfu} / \mathrm{mL})\end{array}$ & $\begin{array}{c}\text { After MF } \\
(\log \mathrm{cfu} / \mathrm{mL})\end{array}$ & $\begin{array}{c}\text { Total log reduction } \\
(\log \mathrm{cfu} / \mathrm{mL})\end{array}$ \\
\hline Bacillus licheniformis & & & \\
$1.4-\mu \mathrm{m}$ MF membrane & $6.11 \pm 0.53$ & $3.94 \pm 0.13$ & $2.17 \pm 0.64^{\mathrm{a}}$ \\
$\begin{array}{l}\text { 1.2- } \mu \text { m MF membrane } \\
\text { Geobacillus sp. }\end{array}$ & $6.98 \pm 0.08$ & $2.41 \pm 0.15$ & $4.57 \pm 0.09^{\mathrm{b}}$ \\
$\begin{array}{l}1.4-\mu \mathrm{m} \text { MF membrane } \\
1.2-\mu \mathrm{m} \text { MF membrane }\end{array}$ & $6.56 \pm 0.29$ & $\mathrm{ND}^{1}$ & $>6 \log$ \\
\hline
\end{tabular}

${ }^{\mathrm{a}, \mathrm{b}}$ Means within a column with different superscripts differ significantly $(P<0.05)$.

${ }^{1}$ Not detected (counts were below the detection limit of $25 \mathrm{cfu} /$ plate). 


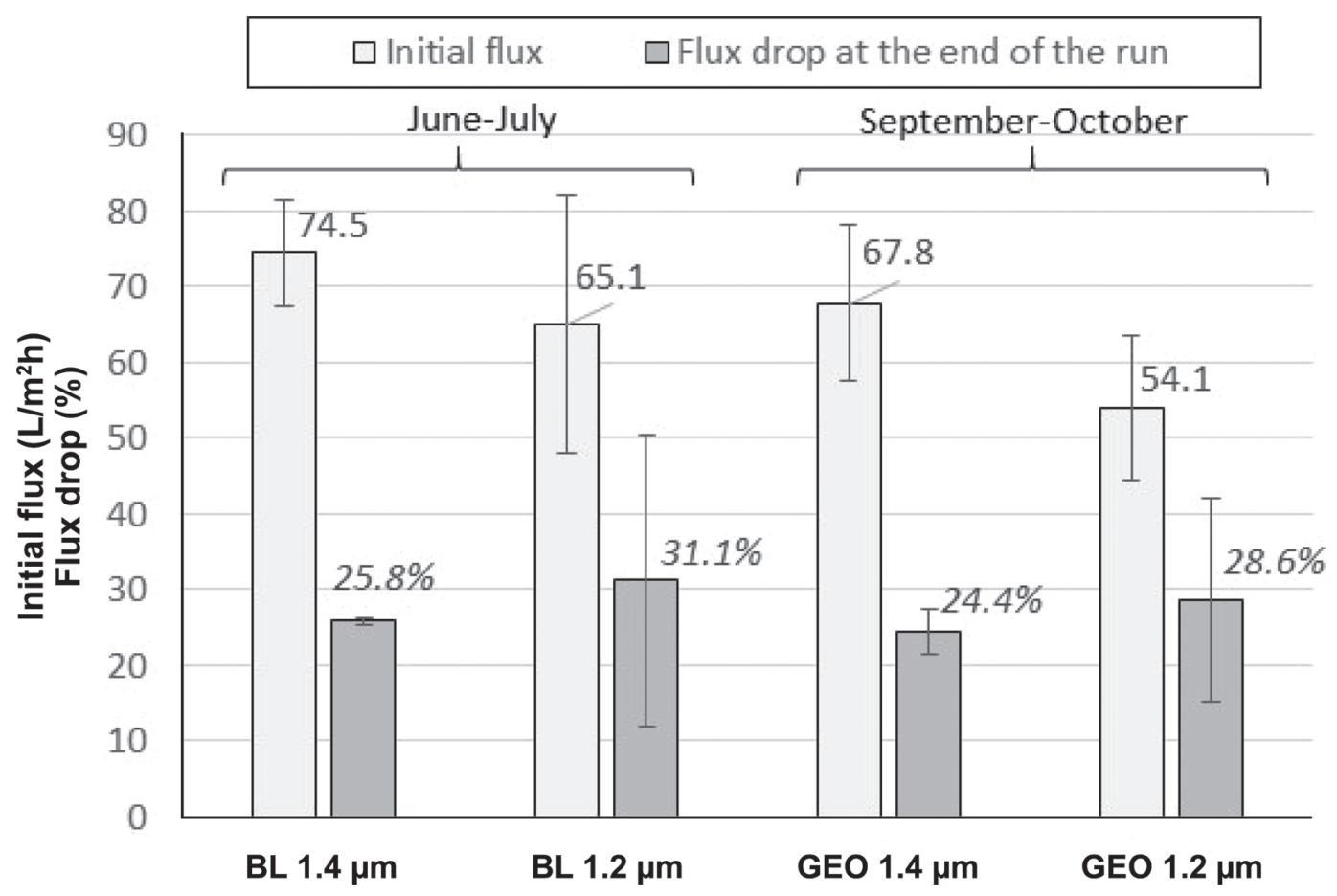

Figure 1. Permeate flux data for the cold microfiltration (MF) of skim milk inoculated with Bacillus licheniformis (BL) and Geobacillus sp. (GEO) spores. The duration of an experimental MF run was 18 to 19 min. Data points represent averages of 3 experimental replicates, with the exception of the B. licheniformis $1.4 \mu \mathrm{m}$ challenge, for which only 2 reliable flux data sets were available. Error bars represent means \pm 1 SD.

spores by the $1.2-\mu \mathrm{m}$ membrane than by the $1.4-\mu \mathrm{m}$ membrane, and the remainder of the paper will focus on the reasons for these differences.

\section{Effect on Spore Size on Removal by MF: Size Matters}

Under scanning electron microscopy, the vegetative cells of both bacterial strains appeared as long rods, characteristic of the genera studied (Figure 2). Vegetative cell length exceeded $2 \mu \mathrm{m}$ and width was less than $0.5 \mu \mathrm{m}$ for both species (Table 3). Although $B$. licheniformis vegetative cells were shorter in length than Geobacillus sp. cells, they occasionally formed long chains, reaching $20 \mu \mathrm{m}$ or more (Figure 1), as has been previously reported (Herben et al., 1990). Vegetative cells of Geobacillus sp. formed either clusters or short chains consisting of 2 to 3 cells (Figure 2). For both species, spores were shorter and wider than their respective vegetative cells, averaging 1.37 to $1.59 \mu \mathrm{m}$ in length and 0.64 to $0.81 \mu \mathrm{m}$ in width (Table 3 ), which is consistent with previously reported spore sizes of Bacillus species (Leuschner et al., 1999; Carrera et al., 2007).

Geobacillus sp. spores $(1.59 \mu \mathrm{m}$ in length and 0.81 $\mu \mathrm{m}$ in width) were, in principle, large enough to be retained by both membranes. At $1.37 \mu \mathrm{m}$ long and $0.64 \mu \mathrm{m}$ wide, $B$. licheniformis spores should be largely

Table 2. Changes in skim milk composition after microfiltration (MF) with 1.4- and 1.2- $\mu \mathrm{m}$ membranes following Geobacillus sp. spore challenge MF runs

\begin{tabular}{|c|c|c|c|c|}
\hline \multirow[b]{2}{*}{ Sample } & \multicolumn{4}{|c|}{ Component } \\
\hline & TS $(\%)$ & Protein (\%) & Lactose $(\%)$ & Fat $(\%)$ \\
\hline Initial skim milk (control) & $9.26 \pm 0.08^{\mathrm{a}}$ & $3.36 \pm 0.04^{\mathrm{a}}$ & $4.63 \pm 0.04^{\mathrm{a}}$ & $0.22 \pm 0.01^{\mathrm{a}}$ \\
\hline Permeate: $1.4 \mu \mathrm{m}$ & $8.96 \pm 0.07^{\mathrm{b}}$ & $3.21 \pm 0.02^{\mathrm{b}}$ & $4.59 \pm 0.03^{\mathrm{a}}$ & $0.15 \pm 0.01^{\mathrm{b}}$ \\
\hline Change $^{2}(\%)$ & -3 & -4 & -1 & -32 \\
\hline Permeate: $1.2 \mu \mathrm{m}$ & $8.73 \pm 0.05^{\mathrm{c}}$ & $3.03 \pm 0.06^{\mathrm{c}}$ & $4.58 \pm 0.03^{\mathrm{a}}$ & $0.12 \pm 0.02^{\mathrm{c}}$ \\
\hline Change (\%) & -6 & -10 & -1 & -45 \\
\hline
\end{tabular}

${ }^{\mathrm{a}-\mathrm{c}}$ Means within a column with different superscripts differ significantly $(P<0.05)$.

${ }^{1}$ Values represent averages of $3 \mathrm{MF}$ runs $\pm 1 \mathrm{SD}$.

${ }^{2}$ Compared with control. 

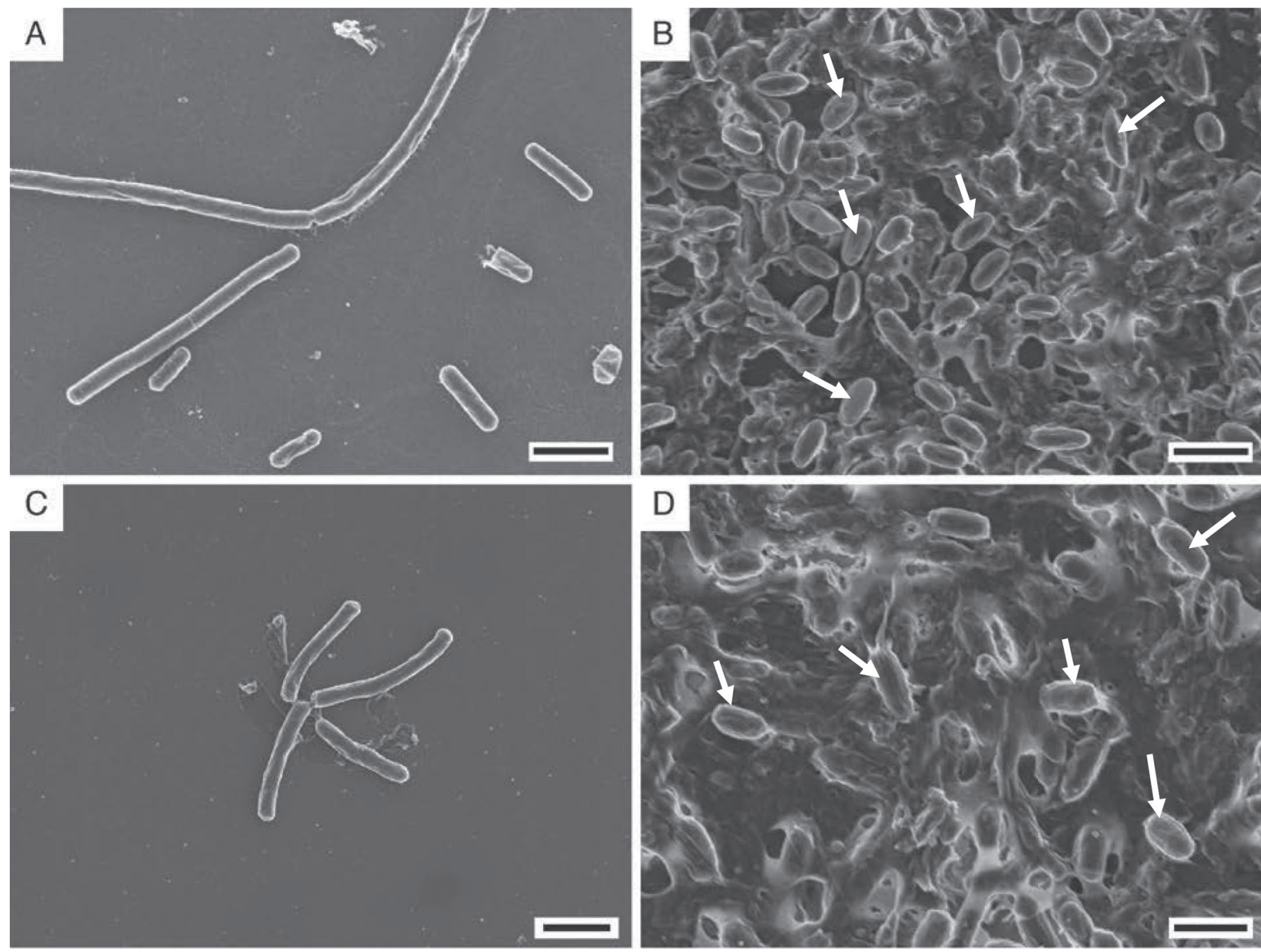

Figure 2. Scanning electron micrographs of vegetative cells and spores, respectively, of Bacillus licheniformis (A, B) and Geobacillus sp. (C, D). The small white arrows in the right panels indicate some examples of spores. Scale bar $=2 \mu \mathrm{m}$.

retained by the $1.2-\mu \mathrm{m}$ membrane but may be able to pass through the $1.4-\mu \mathrm{m}$ membrane in any orientation. The fact that a significant retention of B. licheniformis occurred even with the larger pore size membrane can be explained by (1) membrane fouling; (2) the variability in spore size; or (3) interactions between spores or

Table 3. Measured vegetative cell and spore sizes of Bacillus licheniformis and Geobacillus sp. ${ }^{1}$

\begin{tabular}{lcc}
\hline Bacterial species & Long axis $(\mu \mathrm{m})$ & Short axis $(\mu \mathrm{m})$ \\
\hline B. licheniformis & & \\
Vegetative cell $(\mathrm{n}=12)$ & $2.24 \pm 0.26$ & $0.47 \pm 0.02$ \\
Spore $(\mathrm{n}=19)$ & $1.37 \pm 0.03$ & $0.64 \pm 0.01$ \\
Geobacillus sp. & & \\
Vegetative cell $(\mathrm{n}=9)$ & $2.79 \pm 0.21$ & $0.43 \pm 0.02$ \\
Spore $(\mathrm{n}=16)$ & $1.59 \pm 0.05$ & $0.81 \pm 0.02$ \\
\hline
\end{tabular}

${ }^{1}$ Values represent mean $\pm \mathrm{SE}(\mathrm{n}=9-19$ cells $)$. between spores and the membrane material. Membrane fouling may have played a role, but it was minimal for this membrane pore size (see Figure 1, Table 2) due to carefully chosen processing parameters, as well as the short run time. Although the short run time does not reflect standard industry practices (minutes vs. hours), it was necessary for this particular study to determine the full extent to which spores may be able to pass through an unfouled membrane. As fouling develops, increased spore retention is expected because of blocked or constricted membrane pores, thereby improving overall spore removal in the permeate. The results presented here represent the "worst-case scenario" for spore removal by a largely unfouled membrane. Overall spore removal may actually be higher in industrial applications (which would use much longer run times) due to fouling, although fouling will also negatively 


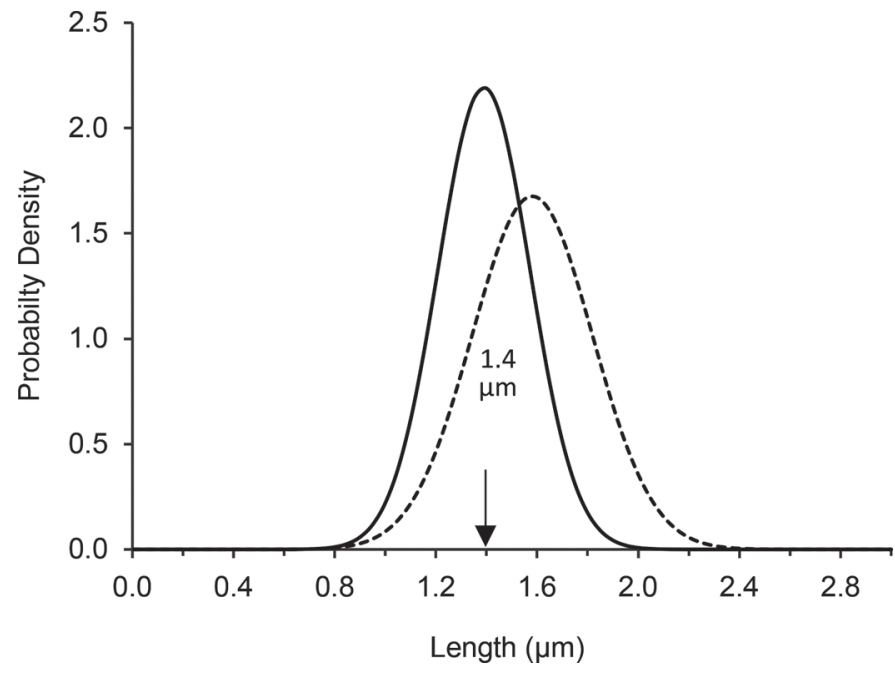

Figure 3. Gaussian distribution of spore lengths $(\mu \mathrm{m})$ for Bacillus licheniformis (solid line) and Geobacillus sp. (dashed line) generated based on measured cell sizes. The arrow indicates $1.4 \mu \mathrm{m}$, which is the nominal pore size average of the commercial microfiltration membrane.

affect protein permeation, decreasing the final protein content in the MF milk.

Because fouling was minimal in this study, we cannot explain why only about $0.7 \%$ of the initial spores passed into the permeate. Thus, we will focus on the other 2 possible causes.

As discussed before, size is a crucial factor in membrane filtration. The values in Table 3 were used to generate a Gaussian distribution for spore size (Figure 3 ), which was then used to calculate the probability that spore lengths were less than 1.4 and $1.2 \mu \mathrm{m}$ for each strain. Based on the generated distributions, $B$. licheniformis spores have a $58.7 \%$ probability of being shorter than $1.4 \mu \mathrm{m}$, and only a $10.7 \%$ probability of being shorter than $1.2 \mu \mathrm{m}$. Geobacillus sp. spores are less likely to pass through $1.4-\mu \mathrm{m}$ pores $(15.2 \%$ chance), and even less likely to pass through $1.2-\mu \mathrm{m}$ pores $(1.6 \%$ chance). An additional factor that needs to be considered is the distribution of membrane pore size (data not available). Nominal pore sizes listed by the manufacturer for these membranes represent average values, but it is known that membranes typically have a pore size distribution (Saboyainsta and Maubois, 2000). Although current ceramic membranes have a relatively narrow pore size distribution, it is to be expected that pores both larger and smaller than the nominal pore size exist for both types of membranes. Some variability in the membrane structure can be observed in scanning electron micrographs of ceramic membranes similar to those used in the current study in the papers by Fritsch and Moraru (2008) and Tan et al. (2014). Therefore, shorter Geobacillus sp. spores could have passed through the larger pores of the 1.4$\mu \mathrm{m}$ membrane, which was not the case experimentally. Therefore, possible interactions between spores or between spores and the membrane material also need to be considered.

\section{Contribution of Spore-Spore and Spore-Membrane Interaction Forces}

Zeta potential and surface hydrophobicity for the microbial cells and the membrane material were determined and used to examine the possibility of interactions between spores and the MF membrane (Table 4).

Both the microbial cells (vegetative cells and spores) and the membrane were found to be negatively charged at an ionic strength equal to that of milk, which is consistent with previous reports (Ankolekar and Labbé,

Table 4. Zeta potential, contact angle measurements, and Gibbs free energy values for an unused ceramic membrane and Bacillus licheniformis and Geobacillus sp. cell suspensions ${ }^{1}$

\begin{tabular}{|c|c|c|c|c|c|c|c|c|}
\hline \multirow{2}{*}{$\begin{array}{l}\text { Species and } \\
\text { material }\end{array}$} & \multirow{2}{*}{$\begin{array}{l}\text { Zeta potential at } \\
20^{\circ} \mathrm{C}(\mathrm{mV})\end{array}$} & & & & \multicolumn{4}{|c|}{ Gibbs free energy ${ }^{2}\left(\mathrm{~mJ} / \mathrm{m}^{2}\right)$} \\
\hline & & $\theta_{\text {Water }}$ & $\theta_{\text {Glycerol }}$ & $\theta_{\text {Diiodomethane }}$ & $\Delta G_{\mathrm{bwb}}$ & $\Delta G_{\mathrm{bws}}$ & $\Delta G_{\mathrm{bwb}}$ & $\Delta G_{\mathrm{bws}}$ \\
\hline \multicolumn{9}{|l|}{ B. licheniformis } \\
\hline Vegetative cells & $-15.62 \pm 0.13$ & $36.63 \pm 1.24$ & $76.20 \pm 2.41$ & $80.62 \pm 2.06$ & 83.37 & 59.02 & 81.65 & 59.63 \\
\hline Spores & $-14.71 \pm 0.73$ & $38.76 \pm 2.15$ & $67.00 \pm 4.08$ & $<10$ & 27.72 & 39.25 & 32.38 & 40.03 \\
\hline \multicolumn{9}{|l|}{ Geobacillus sp. } \\
\hline Spores & $-10.39 \pm 0.42$ & $80.56 \pm 4.05$ & $78.71 \pm 8.29$ & $50.74 \pm 2.78$ & -35.94 & 4.19 & -30.26 & 6.77 \\
\hline Ceramic membrane & $-45.57 \pm 3.28$ & $<10$ & $27.67 \pm 1.78$ & $<10$ & \multicolumn{4}{|c|}{$\mathrm{NA}^{4}$} \\
\hline
\end{tabular}

${ }^{1}$ Values represent mean $\pm \mathrm{SE}$ ( $\mathrm{n}=3$ for all measurements).

${ }^{2}$ Gibbs free energy values of aggregation $\left(\Delta G_{\mathrm{bwb}}\right)$ and attachment $\left(\Delta G_{\mathrm{bws}}\right)$ were calculated at both the temperature of zeta potential and contact angle measurements $\left(20^{\circ} \mathrm{C}\right)$ and the temperature of the microfiltration runs $\left(6^{\circ} \mathrm{C}\right)$.

${ }^{3}$ The surface tension components $\left(\gamma_{\mathrm{LW}}\right.$ and $\left.\gamma_{\mathrm{AB}}\right)$ at $6^{\circ} \mathrm{C}$ were calculated using data extrapolated from Zdziennicka et al. (2017).

${ }^{4} \mathrm{NA}=$ not applicable. 
2010; Palmer et al., 2010). It should also be noted that although the zeta potential for $B$. licheniformis did not change drastically upon sporulation, the charge of Geobacillus sp. spores was twice that of their respective vegetative cells. The ceramic membrane (new, unused material) had a negative charge between 3 and 4.5 times higher than any of the bacterial cells, and thus the membrane should repel both the vegetative cells and spores of both species. Therefore, it is unlikely these slight differences in zeta potential have a significant effect during MF.

Hydrophobicity has been extensively studied in regard to bacterial cell interactions. Spores have generally been found to be more hydrophobic than vegetative cells, which is thought to be a major factor in the stronger attachment of spores - compared with vegetative cells - to stainless steel (Doyle et al., 1984; Rönner et al., 1990; Simmonds et al., 2003). When measured by water contact angle (WCA), bacterial surfaces and cell lawns have been characterized as either very hydrophilic $\left(\mathrm{WCA}<40^{\circ}\right)$, very hydrophobic $\left(\mathrm{WCA}>90^{\circ}\right.$ ), or in between (Mozes and Rouxhet, 1987; Simmonds et al., 2003). In this work, B. licheniformis remained very hydrophilic upon sporulation, with a WCA of $36.63 \pm 1.24^{\circ}$ and $38.76 \pm 2.15^{\circ}$ for vegetative cell and spores, respectively. Geobacillus sp., on the other hand, had very hydrophilic vegetative cells $(\mathrm{WCA}=33.28$ $\left.\pm 1.42^{\circ}\right)$ but became significantly $(P<0.05)$ more hydrophobic in spore form $\left(\mathrm{WCA}=80.56 \pm 4.05^{\circ}\right.$ ). Although previous researchers found spores within the genus of Geobacillus to be hydrophilic (Seale et al., 2008), others have noted that it is possible for bacterial strains within the same genus to range from hydrophilic to hydrophobic, and that hydrophobicity may change depending on growth medium, temperature, and method for measurement (Mozes and Rouxhet, 1987; van der Mei et al., 1998; Simmonds et al., 2003). The new (unused) membrane material was very hydrophilic. However, Tan et al. (2014) reported that although ceramic membranes begin as hydrophilic, adsorption and deposition of milk proteins during MF processing leads to a more hydrophobic membrane surface. The implication is that there might be differences in cell removal by the membrane even over the course of the MF process, as fouling develops.

In addition to this assessment of surface hydrophobicity, we estimated the Gibbs free energy of aggregation $\left(\Delta G_{\mathrm{bwb}}\right)$ and attachment $\left(\Delta G_{\mathrm{bws}}\right)$. These calculations are based on contact angle measurements performed with 3 liquids that differ in polarity and water solubility. Using this approach, the van der Waals and acid-base components of the interaction forces between cells and between cells and the membrane surface can be accounted for, resulting in a more complete picture of their thermodynamic interactions. In an aqueous environment such as milk, hydrophobic particles tend to aggregate, resulting in a $\Delta G_{\mathrm{bwb}}<0$, whereas hydrophilic particles $\left(\Delta G_{\mathrm{bwb}}>0\right)$ favor water and have no tendency to reduce surface area through clustering. Similarly, a negative $\Delta G_{\mathrm{bws}}$ would indicate thermodynamic attraction to a surface, whereas a positive $\Delta G_{\mathrm{bws}}$ indicates no thermodynamic attraction. The Gibbs free surface energies for the unused ceramic membrane material, as well as the B. licheniformis and Geobacillus sp. cell suspensions, are shown in Table 4. Most of the results are consistent with those obtained from the WCA measurements alone, and therefore will not be discussed. The most notable information is that, based on the value of the Gibbs free energy of aggregation the hydrophobic Geobacillus sp. spores tend to cluster in an aqueous environment of milk, at both $20^{\circ} \mathrm{C}\left(\Delta G_{\mathrm{bwb}}=\right.$ $\left.-35.94 \mathrm{~mJ} / \mathrm{m}^{2}\right)$ and at $6^{\circ} \mathrm{C}$, the temperature of the $\mathrm{MF}$ runs $\left(\Delta G_{\mathrm{bwb}}=-30.26 \mathrm{~mJ} / \mathrm{m}^{2}\right)$. The larger size of the clusters compared with individual cells would prevent their passage through the MF membrane, which better justifies the full retention of these spores by the $1.4-\mu \mathrm{m}$ membrane.

\section{CONCLUSIONS}

These results demonstrated that although vegetative bacterial cells are effectively removed from skim milk using 1.4- $\mu \mathrm{m}$ MF membranes, spores may require a smaller pore size for effective removal because of their smaller size compared with vegetative cells. In a challenge study, physical removal of B. licheniformis spores was significantly increased when MF pore size was decreased from 1.4 to $1.2 \mu \mathrm{m}$. An evaluation of surface interactive elements was useful in identifying the thermodynamic tendency of Geobacillus sp. spores to cluster, which helped their removal by MF, even when using a 1.4- $\mu \mathrm{m}$ membrane. Conversely, some $B$. licheniformis were still able to pass through the $1.2-\mu \mathrm{m}$ membrane. A negative consequence of the reduced pore size was a greater reduction of milk protein concentration in the MF milk by the smaller pore size membrane. This was attributed to increased retention of casein micelles by the smaller membrane, which indicates the need to optimize processing parameters for the MF process, but also to identify economical retentate processing solutions in commercial applications. This study also demonstrated that, in addition to pore size, the physico-chemical surface properties of the milk components retained by the membrane can affect the outcome of filtration and thus need to be considered. Overall, there could be additional benefits for microbial removal efficiency by slightly reducing MF membrane pore size to produce low-spore-count milk and dairy 
products, which can lead to quality, safety, and economic benefits for the dairy industry.

\section{ACKNOWLEDGMENTS}

This project was funded by the New York State Milk Promotion Advisory Board (Albany, NY). We thank the Cornell University Milk Quality Improvement Program (Ithaca, NY) for providing the bacterial isolates, and Nicole Martin and Dave Kent for their expertise and assistance in spore growth and harvesting. We also thank João Paulo Almeida Lima, Ioan Gitsov, Linran Wang, and Samantha VanWees for their assistance in MF experiments and microbial testing, and Genevieve Sullivan (all from Cornell University, Ithaca, NY) for her assistance with contact angle measurements.

\section{REFERENCES}

Anand, S., D. Singh, M. Avadhanula, and S. Marka. 2014. Development and control of bacterial biofilms on dairy processing membranes. Compr. Rev. Food Sci. Food Saf. 13:18-33. https://doi .org/10.1111/1541-4337.12048.

Ankolekar, C., and R. G. Labbé. 2010. Physical characteristics of spores of food-associated isolates of the Bacillus cereus group. Appl. Environ. Microbiol. 76:982-984. https://doi.org/10.1128/ AEM.02116-09.

Brans, G., C. G. P. H. Schroën, R. G. M. van der Sman, and R. M. Boom. 2004. Membrane fractionation of milk: State of the art and challenges. J. Membr. Sci. 243:263-272. https://doi.org/10.1016/j .memsci.2004.06.029.

Burgess, S. A., D. Lindsay, and S. H. Flint. 2010. Thermophilic bacilli and their importance in dairy processing. Int. J. Food Microbiol. 144:215-225. https://doi.org/10.1016/j.ijfoodmicro.2010.09.027.

Carrera, M., R. O. Zandomeni, J. Fitzgibbon, and J. L. Sagripanti. 2007. Difference between the spore sizes of Bacillus anthracis and other Bacillus species. J. Appl. Microbiol. 102:303-312. https:// doi.org/10.1111/j.1365-2672.2006.03111.x.

Corbett, J. C. W., F. McNeil-Watson, R. O. Jack, and M. Howarth. 2012. Measuring surface zeta potential using phase analysis light scattering in a simple dip cell arrangement. Colloids Surf. A Physicochem. Eng. Asp. 396:169-176. https://doi.org/10.1016/j .colsurfa.2011.12.065.

Crielly, E. M., N. A. Logan, and A. Anderton. 1994. Studies on the Bacillus flora of milk and milk products. J. Appl. Bacteriol. 77:256263. https://doi.org/10.1111/j.13652672.1994.tb03072.x.

De Jonghe, V., A. Coorevits, J. De Block, E. Van Coillie, K. Grijspeerdt, L. Herman, P. De Vos, and M. Heyndrickx. 2010. Toxinogenic and spoilage potential of aerobic spore-formers isolated from raw milk. Int. J. Food Microbiol. 136:318-325. https://doi.org/10 .1016/j.ijfoodmicro.2009.11.007.

Doyle, R. J., F. Nedjat-Haiem, and J. S. Singh. 1984. Hydrophobic characteristics of Bacillus spores. Curr. Microbiol. 10:329-332.

Elwell, M. W., and D. M. Barbano. 2006. Use of microfiltration to improve fluid milk quality. J. Dairy Sci. 89:E20-E30.

Feng, G., Y. Cheng, S. Wang, L. C. Hsu, Y. Feliz, D. A. Borca-Tasciuc, R. W. Worobo, and C. I. Moraru. 2014. Alumina surfaces with nanoscale topography reduce attachment and biofilm formation by Escherichia coli and Listeria sp. Biofouling 30:1253-1268. https:// doi.org/10.1080/08927014.2014.976561.

Feng, G., Y. Cheng, S. Y. Wang, D. A. Borca-Tasciuc, R. W. Worobo, and C. I. Moraru. 2015. Bacterial attachment and biofilm formation on surfaces are reduced by small-diameter nanoscale pores: How small is small enough? NPJ Biofilms Microbiomes 1:15022.
Flint, S., J. Palmer, K. Bloemen, J. Brooks, and R. Crawford. 2001 The growth of Bacillus stearothermophilus on stainless steel. J. Appl. Microbiol. 90:151-157. https://doi.org/10.1046/j.1365-2672 .2001.01215.x.

Frank, J. F., and A. E. Yousef. 2004. Tests for groups of microorganisms. Pages 227-248 in Standard Methods for the Examination of Dairy Products. 17th ed. H. M. Wehr and J. F. Frank, ed. Am. Public Health Assoc., Washington, DC.

Fritsch, J., and C. I. Moraru. 2008. Development and optimization of a carbon dioxide-aided cold microfiltration process for the physical removal of microorganisms and somatic cells from skim milk. J. Dairy Sci. 91:3744-3760. https://doi.org/10.3168/jds.2007-0899.

Gaillard, S., I. Leguerinel, and P. Mafart. 1998. Model for combined effects of temperature, $\mathrm{pH}$ and water activity on thermal inactivation of Bacillus cereus spores. J. Food Sci. 63:887-889. https://doi .org/10.1111/j.1365-2621.1998.tb17920.x.

Herben, P. F. G., N. Mozes, and P. G. Rouxhet. 1990. Variation of the surface properties of Bacillus licheniformis according to age, temperature and aeration. Biochim. Biophys. Acta 1033:184-188. https://doi.org/10.1016/0304-4165(90)90010-T.

Hoffmann, W., C. Kiesner, I. Clawin-Rädecker, D. Martin, K. Einhoff, P. C. Lorenzen, H. Meisel, P. Hammer, G. Suhren, and P. Teufel. 2006. Processing of extended shelf life milk using microfiltration. Int. J. Dairy Technol. 59:229-235. https://doi.org/10.1111/j.1471 $-0307.2006 .00275 . x$.

Holm, S., R. Malmberg, and K. Svensson. 1986. Method and plant for producing milk with a low bacterial content. US Pat. No. PCT WO 86/01687. Current assignee: Tetra Laval Holdings and Finance SA; original assignee: Alfa Laval Food and Dairy Engineering $\mathrm{AB}$.

Kochkodan, V. M., N. Hilal, V. V. Goncharuk, L. Al-Khatib, and T. I. Levadna. 2006. Effect of the surface modification of polymer membranes on their microbiological fouling. Colloid J. 68:267-273. https://doi.org/10.1134/S1061933X06030021.

Leuschner, R. G. K., A. C. Weaver, and P. J. Lillford. 1999. Rapid particle size distribution analysis of Bacillus spore suspensions. Colloids Surf. B Biointerfaces 13:47-57. https://doi.org/10.1016/ S0927-7765(98)00112-X

Lücking, G., M. Stoeckel, Z. Atamer, J. Hinrichs, and M. EhlingSchulz. 2013. Characterization of aerobic spore-forming bacteria associated with industrial dairy processing environments and product spoilage. Int. J. Food Microbiol. 166:270-279. https://doi .org/10.1016/j.ijfoodmicro.2013.07.004.

Mozes, N., and P. G. Rouxhet. 1987. Methods for measuring hydrophobicity of microorganisms. J. Microbiol. Methods 6:99-112.

Palmer, J. S., S. H. Flint, J. Schmid, and J. D. Brooks. 2010. The role of surface charge and hydrophobicity in the attachment of Anoxybacillus flavithermus isolated from milk powder. J. Ind. Microbiol. Biotechnol. 37:1111-1119. https://doi.org/10.1007/s10295 $-010-0758-x$.

Parkar, S. G., S. H. Flint, J. S. Palmer, and J. D. Brooks. 2001. Factors influencing attachment of thermophilic bacilli to stainless steel. J. Appl. Microbiol. 90:901-908. https://doi.org/10.1046/j .1365-2672.2001.01323.x.

Postollec, F., A. G. Mathot, M. Bernard, M. L. Divanac'h, S. Pavan, and D. Sohier. 2012. Tracking spore-forming bacteria in food: From natural biodiversity to selection by processes. Int. J. Food Microbiol. 158:1-8. https://doi.org/10.1016/j.ijfoodmicro.2012.03 .004 .

Ranieri, M. L., and K. J. Boor. 2010. Tracking and eliminating sporeformers in dairy systems. Aust. J. Dairy Technol. 65:74-80.

Rönner, U., U. Husmark, and A. Henriksson. 1990. Adhesion of bacillus spores in relation to hydrophobicity. J. Appl. Bacteriol. 69:550556. https://doi.org/10.1111/j.1365-2672.1990.tb01547.x.

Rückert, A., R. S. Ronimus, and H. W. Morgan. 2004. A RAPD-based survey of thermophilic bacilli in milk powders from different countries. Int. J. Food Microbiol. 96:263-272. https://doi.org/10.1016/ j.ijfoodmicro.2004.03.020.

Saboyainsta, L., and J. L. Maubois. 2000. Current developments of microfiltration technology in the dairy industry. Le Lait 80:541-553. 
Scheldeman, P., L. Herman, S. Foster, and M. Heyndrickx. 2006. Bacillus sporothermodurans and other highly heat-resistant spore formers in milk. J. Appl. Microbiol. 101:542-555. https://doi.org/ 10.1111/j.1365-2672.2006.02964.x

Schmidt, V. S. J., V. Kaufmann, U. Kulozik, S. Scherer, and M. Wenning. 2012. Microbial biodiversity, quality and shelf life of microfiltered and pasteurized extended shelf life (ESL) milk from Germany, Austria and Switzerland. Int. J. Food Microbiol. 154:1-9. https://doi.org/10.1016/j.ijfoodmicro.2011.12.002.

Seale, R. B., S. H. Flint, A. J. McQuillan, and P. J. Bremer. 2008. Recovery of spores from thermophilic dairy bacilli and effects of their surface characteristics on attachment to different surfaces. Appl. Environ. Microbiol. 74:731-737. https://doi.org/10.1128/ AEM.01725-07.

Simmonds, P., B. L. Mossel, T. Intaraphan, and H. C. Deeth. 2003. Heat resistance of bacillus spores when adhered to stainless steel and its relationship to spore hydrophobicity. J. Food Prot. 66:2070-2075.

Tan, T. J., D. Wang, and C. I. Moraru. 2014. A physicochemical investigation of membrane fouling in cold microfiltration of skim milk. J. Dairy Sci. 97:4759-4771. https://doi.org/10.3168/jds.2014 $-7957$.

Tang, X., S. H. Flint, J. D. Brooks, and R. J. Bennett. 2009. Factors affecting the attachment of micro-organisms isolated from ultrafiltration and reverse osmosis membranes in dairy processing plants.
J. Appl. Microbiol. 107:443-451. https://doi.org/10.1111/j.1365 $-2672.2009 .04214 . \mathrm{x}$

Tomasula, P. M., S. Mukhopadhyay, N. Datta, A. Porto-Fett, J. E. Call, J. B. Luchansky, J. Renye, and M. Tunick. 2011. Pilot-scale crossflow-microfiltration and pasteurization to remove spores of Bacillus anthracis (Sterne) from milk. J. Dairy Sci. 94:4277-4291. https://doi.org/10.3168/jds.2010-3879.

van der Mei, H. C., R. Bos, and H. J. Busscher. 1998. A reference guide to microbial cell surface hydrophobicity based on contact angles. Colloids Surf. B Biointerfaces 11:213-221. https://doi.org/ 10.1016/S0927-7765(98)00037-X

Walkling-Ribeiro, M., O. Rodríguez-González, S. Jayaram, and M. W. Griffiths. 2011. Microbial inactivation and shelf life comparison of 'cold' hurdle processing with pulsed electric fields and microfiltration, and conventional thermal pasteurisation in skim milk. Int. J. Food Microbiol. 144:379-386. https://doi.org/10.1016/j .ijfoodmicro.2010.10.023.

Watterson, M. J., D. J. Kent, K. J. Boor, M. Wiedmann, and N. H. Martin. 2014. Evaluation of dairy powder products implicates thermophilic sporeformers as the primary organisms of interest. J. Dairy Sci. 97:2487-2497.

Zdziennicka, A., J. Krawczyk, K. Szymczyk, and B. Jańczuk. 2017. Components and parameters of liquids and some polymers surface tension at different temperature. Colloids Surfaces A Physicochem. Eng. Asp. 529:864-875. 